\title{
The Role of Technology in Nigerian Catfish Production: AReview
}

Samuel ljabo Ogah, Goshen David Miteu, Emmanuel Oluwasogo Oyewole, Josephine Oluseyi Adebayo, Elohozino Oghale Benneth

10.18805/ag.RF-219

\begin{abstract}
This article examines the state of Catfish production in Nigeria and the roles technology has played over the past decades. Heightened demand as a result of increased population puts considerable pressure on production. In response to this pressure aquaculturists ramped up production activities, this demand-driven increase exposes the major gaps as the industry struggles to cope with the absence of fundamental structures like inadequate structured funding, markets, processing and preservation facilities among others. Such gaps exist in all aspects of aquaculture and technology is a viable plug for many of them. The aquaculture of developing nations has certain peculiarities which predispose it to slow development. Many fishermen and aquaculturists in low-income regions are trapped in economic systems that result in relative poverty. Many reasons have been put forward to explain the dynamics behind these consequences with technology playing a major role from the consensus. Rapid advances in hatchery, water quality and molecular technology have been identified as some of the active drivers of Catfish production in Nigeria. The article focuses on the history, progress and prospects of aquaculture technology in Nigeria. It does so by reviewing the technologies already established in Catfish farming and the impact of their roles in balancing fish demand and supply.
\end{abstract}

Key words: Catfish production, Fish farming, Nigerian aquaculture, Technology.

The increase in population which naturally comes with the increase in demand for cheap protein has necessitated the need for diversified means of rearing fish and other aquatic organisms as against relying wholly on the natural supply from water bodies (Dauda et al., 2018). In a bid to save and supplement the high demand on Nigerian waters as a result of fish supply (Grema et al., 2011), aquaculture as seen in other developed or developing countries of the world found its way into the country. It is the maintenance of aquatic organisms under a controlled environment and has the potential of bridging the widened gap of fish supply in Nigeria against its demand (Dauda et al., 2013). According to Adewunmi et al., (2011), Nigeria is the largest consumer of fish in Africa and a key consumer in the world at large with an annual demand of 2.1 million metric tons per year. Due to the complexity of the aquatic habitat, the enviable potential of aquaculture (broadly aquatic flora and fauna) has become uncertain. Adewunmi et al., (2011), reported that fish farming in Nigeria alternately referred to as Catfish production, serves as the major fish species cultured in the country and is characterized by high resistance to diseases, high acceptance and affordable. African catfish which is a common name of the family Clariidae with Clarias gariepinus as the most reared, is an important fish species cultured in various regions of the world (Dauda et al., 2018). Nigeria tops the list of producing countries followed by the Netherlands, Brazil and others (FAO, 2016). However, the successful development of artificial propagation protocols in the 1980's in Nigeria can be linked to the success of African Catfish farming with substantial contribution to aquaculture development in the rnid-1990s (FAO, 2016). According to Ozigbo et al., (2014), factors mitigating catfish production in Nigeria include impecunious management
Food and Agricultural Technology-PARG [Pan African Research Group], Nigeria.

Corresponding Author: Samuel ljabo Ogah, Department of Fisheries and Aquaculture, Federal University Gashua, Nigeria. Email: samuelogah44@fugashua.edu.ng

How to cite this article: Ogah, S.I., Miteu, G.D., Oyewole, E.O., Adebayo, J.O. and Benneth, E.O. (2022). The Role of Technology in Nigerian Catfish Production: A Review. Agricultural Reviews. DOI: $10.18805 /$ ag.RF-219.

Submitted: 13-08-2021 Accepted: 04-12-2021 Online: 06-01-2022

skills, insufficient stock of good quality seed, shortage of investment, high prices of feed, unreliable data collection, as well as non-existent concern for environmental impact and marketing of products.

Nwachukwu and Onuegbu (2007), firmly expressed their belief that introducing technologies amongst others is the way forward in developing aquaculture in Nigeria. The various aspects of aquaculture can be advanced with the introduction of the right technologies and ultimately make them available for use by every fish farmer and aquaculturists (Joshua and Omidiji, 2002). Many fishermen and aquaculturists in low-income regions are trapped in economic systems that result in relative poverty (Watanabe, et al., 2001). Many reasons have been put forward to explain the dynamics behind these consequences with technology playing a major role from the consensus (Pollnac, 1985). Though the technologies used have changed with locally available resources and socioeconomic realities, there is always room for upgrade. Advances from other industries have been successfully copied and used to enhance artisanal fishing and aquaculture (Walsh et al., 2002) which 
is especially true in developing nations with improvisation being rather common. While recognizing that there are myriads of problems faced by the small-scale fisherman and aquaculturists in the third world countries like Nigeria, this article will focus on the use of technology. There are no universal answers in fisheries and aquaculture technologies, as each community or unit should be studied individually to determine the technologies that are applicable to its specific conditions (Ben-Yami, 1984; Ben-Yami and Anderson, 1985). For example, in some parts of Nigeria, fisheries and aquaculture are predominantly run by men with the tools and systems fashioned by men for men and this has continued for many decades. This factor will be reflected in type of technology used with regards to a bias due to gender imbalance. Also, this study is important because $50 \%$ of the 15 million artisanal fishermen fishing full time live and work in the developing regions of the world and other 15 million fish processors who reside in the same region (Compte, et al., 1984; National Research Council, 1988). For the families of these millions and the many others whom they serve, fish caught and reared by traditional methods are their primary protein source (Poggie, 1980). Traditional fisheries may be commercial or subsistence, but they each have in common a small cash income (Yagi et al., 2008). Fishing productivity in the artisanal sector is consequently variable and low; many fishermen catch only one or two tons of fish per year (Ward et al., 2002; McArthur and Sachs, 2002). Therefore, this study was carried out to review technologies already established in advancing catfish farming and the impact of their roles in balancing fish demand and supply, as well as point out other technologies that would propel active development in the catfish industry.

\section{Methodology}

This study was conceptualized and research carried out at the Food and Agriculture Unit of the Pan African Research Group (FAT-PARG) in April-July 2021. Relevant literature was sourced online and offline from research repositories like Google scholar, African Journals Online (AJOL), Agricultural Research Communication Centre (ARCC) and Federal University Gashua and FAT-PARG libraries respectively. 209 online sources (research articles and webpages) and 35 offline sources were accessed and further narrowed to 115 of the most recent and relevant materials which were examined in the preparation of this review.

\section{History of technology use in Nigerian aquaculture}

From the inception of agriculture centuries ago, man has always been interested in fish farming as a source of food, income and increasing productivity level over the years as technology advanced (Wuyep and Rampedi, 2018). Nigerian aquaculture used to be operated on a small scale but with timely intervention in the advent of technology, aquaculture has advanced to a commercialized system as seen today in intensive fish farming (Akinola et al., 2006). In the recent past decades, Nigerian aquaculture has made use of oldfashioned means revolving around wetlands and coastal plains of inland waters. In recent times however, with the introduction of the cage culture system development in aquaculture has focused more on the coastal region. In Africa, aquaculture has numerous opportunities for largescale production with Nigeria being one of the top producers and small-scale farmers who are involved in freshwater and brackish cultivation are responsible for $80 \%$ of production. This excludes mariculture and macro algae which have not been fully explored because of the technical and financial limitations that come with it. Cultures for fish were facilitated by creating earthen ponds and tanks with dissolved salt less than 0.5 parts per thousand salinity level. Tank cultivation techniques which is capital intensive, are typically produced from fibre glass, PVC plastic, concrete or treated wood (Emmanuel et al., 2014).

Aside cultivation and management, aqua-tech has scaled up fish sustainability in terms of preservation and extending its shelf life for instance, fresh fish can now be processed as desired without any significant loss of quality, unlike in the past (Davies et al., 2008). Smoking used to be the method employed in drying and preserving fish but the primitive nature of traditional processing which is devoid of regulation, occasionally leads to under or over drying and can increase their vulnerability to contaminants from the wind, dust, dirt and flies in the environment (Bolaji, 2005). Although this method is still predominant in Nigeria because of limited access to electricity, the burgeoning interest in fish cultivation has harnessed and adopted the use of solar power, freezing and salting for these purposes (Olokor, 1997). Nigerians are now informed on novel technological practices in aquaculture and their benefits. Microbial activities in fish are inhibited and the shelf life of it prolonged through the emitting heat of the smoking or drying method which reduces the moisture content present (Clucas and Ward, 1996; Oyeleye, 2003; Amoo et al., 2007). After smoking, sun-drying and even salting, several fish species possess astounding preservation 'qualities (Madu et al., 1984). Eves and Brow (1993) further established that two advantages of drying and smoking of fish are improved protein digestibility and better nutritive value.

\section{Trends and prospects of technology in aquaculture}

Technology and its applications have always been a bridge to a better future. Technologies used in aquaculture are not an exception. Rapid development has been observed from previous decades in aquaculture. An observed evolution has been recorded from simple techniques to high technology systems. Technology is now employed in aquaculture to increase growth and production in order to meet consumer's demand which in turn has proven to shape the economics of the sector by promoting good business (Lazard et al., 2010; FAO, 2010). Genetic tools and many reproductive techniques are now employed to combat the challenge faced previously in aquaculture, resistant strains and stress tolerance can now be infused into fishes which have prevented many diseases and increased the sustainability of aquaculture species in productivity, growth, food 
processing and economy (Renault, 2009). Aquaculture proposes boundless possibilities for technical improvement (Waite et al., 2014). Over the past 50 years, the aquaculture sector has experienced growth as a result of technological developments in breeding methods and production, reproductive control, selection of strain and species, nutrition technology and feeds, vaccines, automated aeration, water exchange as well as non-technological inventions comprising market certification standards, advanced supervisory structures amongst others (Kumar and Engle, 2016; Joffre et al., 2017). Current studies point out that investments in novel inventions, management methods and new products, give rise to significant benefits both to the producers as well as the consumers (Kumar and Engle, 2016). Production processes in aquaculture have become improved (Asche et al., 2005). Advances in technology have created opportunity for fresh management practices, therefore snowballing production in aquaculture from the perspective of labour, output per unit land and water. This increase has correspondingly reduced production costs and amplified market competition (Barazi-Yeroulanos, 2010). Some of the trends and prospects of technology in aquaculture are discussed in this article.

\section{Aquaculture reproduction}

Advances have been made to enhance certain aspects of the fish life cycle in fish reproduction. Through hatchery technology, juveniles can be produced in any season and can be selectively bred to boost growth and disease resistance. The technology of selective breeding has birthed salmon breeding companies to aid selection making use of quantitative trait loci (QTL) and genotyping, leading to introduction of strains that are highly resistant to infectious pancreatic necrosis (IPN), a viral disease that previously ravaged produce (Houston et al., 2010). Biotechnology and genetics play a large role in increasing the productivity of the ecosystem and enhancing its sustainability. Identification and conservation of aquatic biodiversity is now possible with recent innovated technologies in aquaculture. Transgenic technology is a major highlight of innovation which has been useful in reproduction, an example is the transgenic shrimp which was bred (Mialhe et al.,1995) and has been improved in recent times. Transgenic technology is useful in enhancement of growth rates, market size, feed conversion, disease resistance, improvement of stress tolerance against extreme environmental conditions and solving sterility issues. In order to aid identification of genes that are salient biomarkers for disease vulnerability, growth, as well as sex determining factors, genetic markers such as short unique genetic codes have been developed (Kocher et al., 1998). Through these markers, genetic upgrade and improvements of Catfish, Salmon, Tilapia and other cultured fish species are induced. These novel techniques have helped farmers to overcome the drawbacks of some traditional techniques which reduced production estimates. Different projects are being carried out by research institutions to examine and further understand the genetic sequence of some species.
A typical example is the Genetically Improved Farmed Tilapia (GIFT) program.

\section{Feed technology}

One of the most challenging issues faced in aquaculture is the cost of aqua-feeds proteins especially fishmeal (Forster, 2008; Naylor et al., 2000). Although fishmeal has a high protein content, the cost and availability is a challenge making it necessary to find substitutes and supplement with plant proteins. This is where technology comes into play as biotechnology provides the means to develop a suitable alternative to fish meal, enhancing production and processing techniques by using plant protein (Mendoza et al., 2001). However, the use of plant seeds and leaves as protein supplements poses certain problems for mollusks and finfish due to the presence of anti-nutritional factors (Papatryphon and Soares, 2001; Vielma et al., 2000). Nutrition in aquaculture has been enriched as there are new formulas for diets. Diets can now be fully formulated which in turn is expediting the escalation and emergence of notable industries such as catfish, tilapia, shrimp salmon, sea bream, sea bass and trout (FAO, 2010). Now, different companies have their respective feed formulas to match specific needs of production systems and final markets. A company may employ the use of one or more type(s) of technology depending on their target economic scale. For example, a company can engage procedures such as coated vacuums and sealed pellets solely to protect as well as increase the lipid content which supports a much higher and efficient conversion of fishmeal to aquaculture produce at a lower production cost (Refstie and Asgard, 2009).

\section{Disease management}

Fish health has been greatly improved by technology. The disease conditions and death rates have been lowered when compared with previous decades (Pulkkinen et al., 2010). Vaccines have been developed against viral, fungal and bacterial diseases. To initiate immune responses majority of these vaccines were founded on adjuvants of mineral oil and lifeless/metamorphosed cells. This can be seen in the FAO (2010) report where it was recorded that the total death proportion in the Scottish Salmon industry (Scotland) dropped from $38 \%$ in 1997 to $12 \%$ in 2000 with a further decline very recently as a result of sophisticated technological advancements. The quest to find the perfect vaccine started a few decades ago and now molecular tools and technology have progressed in mitigating treatment resistance to some diseases such as sea lice in Atlantic salmon (Alvarez-Pellitero, 2008; OIE, 2001). Recent investigations have concentrated on vaccines contrary to virus-related infections by means of other innovative technology such as peptides, RNA and DNA (Costello, 2009).

There are records of emerging diseases that have affected aquaculture because the traditional approaches towards disease control are no longer effective as a result of the wide range of novel pathogens. Application of molecular techniques for pathogen screening, identification 
and isolation is considered as one of the best solutions to this challenge as these molecular techniques not only contribute the disease control but also provide significant information about the developmental process of diseases, potential control, prevention and treatment of diseases like DNA vaccines. Various DNA or RNA based probes have great potential for easy and timely recognition of infections and detection of their carriers. Cultured and wild species alike have benefitted from nucleic acid-based probe advances in the preventive management and control of disease. These probes have been successful in the selection of shrimp brood stock and breaking infection cycles, due to accidental spread of virus-related pathogens of brood stock to emerging progenies. Two viable accessible molecular investigations are IHHNV and type-A baculo virus in shrimp aquaculture (Durand et al., 1996), but in case of some other viral pathogens like SEMBV, MBV, TSV, HPV and YHV, availability of commercial probes is still under development. Two major advantages of using microbial probes are that; they are extremely sensitive and highly specific which made their use more suitable over non-molecular techniques (Walker and Subasinghe, 2000). Because of their high sensitivity and specificity, they can easily detect microbial infections in advance and can provide more accurate and rapid identification of pathogens respectively.

The wide-spread application of these molecular techniques has helped to reduce dependency on prophylactic treatment and active use of antibiotics for the purpose of disease control. So, their application helped to achieve better intervention of disease management and reduced cost or control. For many fish species, in-vitro tissue culture is available and biotechnological methods are not only useful in pathogen screening but also have other applications for estimations of various health parameters, including phagocytic functions, haematocrits, myeloperoxidase activity, leucocytes and oxidative radical (FAO and NACA, 2001; OIE, 2000; Groff and La Patra, 2000; Chi et al., 1999).

\section{Overall system improvements}

Most early aquaculture practices were reliant on fishponds or creeks. Recent trends are not limited to floating enclosures in exposed aquatic bodies (Fredheim and Langan, 2009). Cage culture is now widely practiced. Some of the prominent designs utilize high-density polyethylene pipes also known as HDPE which were initially made for gas production businesses. In addition to specialized HDPE mouldings, most of the trending cage nets in aquaculture make use of nets from knotless nylon. Nonetheless, newer materials are also being used e.g. (UHMwPE) Ultra-High Molecular weight Poly-Ethylene.

The production of special service vessels like catamaran work boats and well boats are due to advancement in technology, in addition to fish pumps, as well as counting and sorting arrangements has greatly reduced labour requirements thereby enabling huge sections to be proficiently stocked (Forster, 2008). Computerized feed conveying structures with moving feed storage containers are changing into full-service programs with provision of accommodation for employees as well as innovative communication and monitoring schemes. The likelihood of aquaculture being conducted close to market and with minimal environmental discharge is offered by the recirculatory aquaculture systems (RAS). Technology has proffered solutions to natural predators of aquaculture stocks. Improved technological solutions such as the use of scares and protective barriers are now implemented compared to the archaic destructive means like guns to shoot birds (Muir, 2005; Quick et al., 2004). Overtime, it has been argued that harmful therapeutic substances are discharged into the environmental waters (Burridge et al., 2010). Enhanced research laboratory discovery techniques have stimulated better evaluation as well as proper check in this capacity (Peeler et al., 2007).

Management roles in the aquaculture sector have been made easy. At the sector and company level, the eminence and appropriateness of information at the disposal of workers is very important for effective managerial playout of which potent apparatuses needed for support are being provided by Internet of Things (IOT). Geographic Information Systems (GIS) have been able to establish a format for analyzing and displaying a varied range of data using spatial features for planning and regulatory functions as well as for collation and visualization (Ross et al., 2009). ICT has also been identified as a key player in recent market chains. Key supermarkets entail more and more refined market representations to aid the predictive request aimed at specific goods that integrate explicit short-range variables such as campaigns on standby items with probable capacity for increasing or decreasing consumption of perishable goods (Taylor and Fearne, 2009). The information is then transferred in form of frontward orders to the supply chain which are habitually fewer than 24 hours preceding delivery. Therefore, in order to respond correctly, astounding scheduling and logistic information technology is absolutely necessary for producers. In the case of a large salmon company, for instance, which involves assessment of which sites and cages should be harvested to provide the required product, the selection and mobilization of the appropriate processing plant and all the intermediate transport logistics can only be done effectively via technology. Food and feed hint tools are also made available by the ICT systems (Bostock, 2009). McGinnity et al., (2003) revealed that in some ways genetic introgression may possibly result to decreased lifetime aptness and contribute to the deterioration of stocks in Atlantic salmon. Conversely, tangible effects are expected to be swayed by the quantity and rate of recurrence of escapes, extensive characteristics of the setting and indigenous stocks. To keep track of future modifications as well as probe populations where such occurrences have been previously identified, genetic marker analysis plays an important role (Glover et al., 2009). Certain 
situations have instigated proposals that require aquaculture to make use of triploid stock that are sterile or alternatively formulate strains incapable of reproducing in the wild (Wong and Van Eenennaam, 2008). Although the ecological impacts of such proposals are debatable, the reasoning and technology behind it is laudable.

\section{Biotechnological tools}

Biotechnological studies are the only way that implementation and understanding of gene regulation and expression can be possible (Davies, 2005; Agresti et al., 2000; AlcivarWarren, 2001). In the same vein, exploring biotechnological tools for improved cryopreservation of gametes and embryos, transgenic manipulations have yielded many benefits.

\section{Bioremediation}

An alternative approach which seems promising is bioremediation. This allows the use of various aquatic organisms and macro-organisms to degrade harmful waste to a harmless level that is in most cases beneficial to the environment (Rao and Sudha, 1996).

\section{Various enhancement technologies related to aquaculture}

Another new and enhanced technology relating to aquaculture is sea-ranching technology (it is a technology where production of juveniles occurred in the hatcheries, but they are released to the sea to grow), pen cages and aquapods.

Other emerging and modified production systems like biofloc and aquaponics have also promoted Catfish farming in no small way within the last decade. These are technologies that strive to reduce fish feed use rather conditioning the fish to feed on algae and recycle fish waste to grow plants rather than disposing wastewater into the environment causing pollution respectively (Ogah et al., 2020a). Although many farmers did not adopt these technologies swiftly dues to insufficient technical knowledge and finance, they are becoming widespread lately (Ogah et al., 2020b).

\section{CONCLUSION}

This myriad of technologies discussed have improved the practice of Nigerian fisheries and aquaculture in no small way. As the world moves towards more sustainable means of production, more attention would be placed on balancing production with environmental care. Mass production also comes with certain health risks, as continuous consumption of processed food is frowned upon in some medical quarters. The debate on the use of GMO's for enhancing food security especially in developing countries like Nigeria and areas hit by war, famine or natural disasters is likely to continue. Nigerians would have to decide how fast the next wave of technological advances can sweep through as it is a viable market for more developed nations to dispose such products. However the pendulum swings, history will remember Nigeria as a fast adopter and a ready market for novel technologies.

\section{ACKNOWLEDGMENT}

The authors would like to acknowledge "The Pan African Research Group" PARG, its founder and director - Hampo Chima Cyril, as well as the Food and Agricultural Technology Unit of PARG for providing the platform for the conduct of this research. And to our team leaders, Victor Ajimati, Oghenetega Lois, Olayemi Ojeokun and James Godwin, we acknowledge your instrumental efforts in ensuring that this research had a successful outcome.

\section{Author contribution}

1. Samuel ljabo Ogah: Primary Investigator, Conceptualization, Writing-Introduction, Conclusion and Recommendation, Editing and Review, Supervision.

2. Goshen David Miteu: Writing-Literature review and Discussion.

3. Emmanuel Oluwasogo Oyewole: Writing - Introduction.

4. Josephine Oluseyi Adebayo: Conceptualization, WritingReview and Editing.

5. Elohozino Oghale Benneth: Head of Laboratory, Conceptualization, Supervision, Writing-Review and Editing, Initial and Final draft editing.

\section{Funding statement}

The research done for the writing of this review article did not receive any grant or funding from an individual, group nor organization.

\section{Conflict of interest}

The authors use this medium to declare no conflict of interest.

\section{REFERENCES}

Adewumi, A.A., Olaleye, V.F. (2011). Catfish culture in Nigeria: Progress, prospects and problems. African Journal of Agricultural Research. 6(6): 1281-1285.

Agresti, J.J., Seki, S., Cnaani, A., Poompuang, S., Hallerman, E.M., Umiel, N., Hulata, G., Gall, G.A.E. and May, B. (2000). Breeding new strains of tilapia: Development of an artificial centre of origin and linkage map based on AFLP and microsatellite loci. Aquaculture. 185: 43-56.

Akinola, O.A., Akinyemi, A.A. and Bolaji, O. (2006). Evaluation of traditional and solar fish drying systems towards enhancing fish storage and preservation in Nigeria (Abeokuta Local Government as case study). International Journal of Fish. 1: $44-49$

Alcivar-Warren, A. (2001). Shrimp Map: A genetic approach to understand immune response and disease resistance in shrimp. In Aquaculture 2001: Book of Abstracts, World Aquaculture Society, Baton Rouge, LA, USA, p. 11.

Alvarez-Pellitero, P. (2008). Fish immunity and parasite infections: from innate immunity to immunoprophylactic prospects. Veterinary Immunology and Immunopathology. 126: 171-198.

Amoo, I.A., Akinneye, J.O. and Arannilewa, S.T. (2007). Effect of drying methods on the nutritional composition of three species of fish (Bonga sp. Sardinella $s p$. and Heterotis niloticus). International Journal of Fish. 2: 99-103.

Asche, F. et al., (2005). Competition between farmed and wild salmon: The Japanese salmon market. Agricultural Economics. 33(3): 333-340. doi: 10.1111/j.1574-0864.2005.00072.x. 
Barazi-Yeroulanos, L. (2010). Synthesis of the Mediterranean marine Finfish and development strategy for marketing and promotion. Reviews No. 88: Food and Agriculture Organisation of the United Nations.

Ben-Yami, M. (1984). Technology transfer. Parts 1 and 2. World Fishing (September and October issues).

Ben-Yami, M. and Anderson, A.M. (1985). Community Fisheries Centers: Guidelines for Establishment and Operation. Fisheries Technical Paper, 264.

Bolaji, B.O. (2005). Performance Evaluation of a Simple Solar Dryer for Food Preservation. Proceedings of the $6^{\text {th }}$ Annual Engineering Conference of School of Engineering and Technology, May 12-15, 2005, Minna, Nigeria, pp: 8-13.

Bostock, J. (2009). Use of Information Technology in Aquaculture. In: New Technologies in Aquaculture, Woodhead Publishing. (pp 1064-1118).

Burridge, L., Weis, J.S., Cabello, F., Pizarro, J. and Bostick, K. (2010). Chemical use in Salmon aquaculture: A review of current practices and possible environmental effects. Aquaculture. 306: 7-23.

Chi, S.C., Hu, W.W. and Lo, B.J. (1999). Establishment and characterisation of a continuous cell-line (GF-1) derived from grouper, Epinephelus coicoides (Hamilton): A cell line susceptible to grouper nervous necrosis virus (GNNV). Journal of Fish Diseases. 22(3): 173-182.

Clucas, I. and A.R. Ward, (1996). Post-Harvest Fisheries Development: A Guide to Handling, Preservation, Processing and Quality. National Research Institute, UK., ISBN-13: 9780859544 412, pages: 443.

Compte, C., Mouchon, J., Challe, O. and Noaro, P. (1984). Décoder le journal télévisé. Belc.

Costello M.J. (2009). How sea lice from salmon farms may cause wild salmonid declines in Europe and North America and be a threat to fisheries elsewhere. Biological Sciences. 276: 3385-3394.

Dauda, A.B, Folorunso, L.A, Dasuki, A. (2013). Use of probiotics for sustainable aquaculture production in Nigeria. Journal of Agriculture and Social Research. 13: 35-45.

Dauda, A.B., Natrah, I., Karim, M., Kamarudin, M.S., Bichi, A.H. (2018). African catfish aquaculture in Malaysia and Nigeria: Status, trends and prospects. Fish and Aquaculture Journal. 9: 237. doi:10.4172/2150-3508.1000237.

Davies, O.A., R.M. Davies and D.O. Bekibele, (2008). Fish processing technologies in Rivers State. Nigeria Journal of Applied Science. 3: 548-552.

Davies, R.M., (2005). Development of Appropriate Technology of Fish Processing in Nigeria. Proceedings of the Workshop on Intensive Fish Farming, February $24^{\text {th }}$, 2005, Nigeria.

Durand, S., Lightner, D.V., Nunan, L.M., Redman, R.M., Mari, J., and Bonami J.R. (1996). Application of gene probes as diagnostic tools for white spot baculovirus (WSBV) of penaeid shrimp. Aquatic Disease Organisation. 27(1): 59-66.

Emmanuel, O., Chinenye, A., Oluwatobi, A. and Peter, K. (2014). Review of Aquaculture Production and Management in Nigeria. American Journal of Experimental Agriculture. 4(10): 1137-51.

Eves, A. and R. Brow, (1993). Effect of tradition al drying process on the nutritional value of fish. Journal of Tropical Science. 33: 183-189.
FAO (2010). FAO Fishstat Fisheries Statistical Data. Rome: FAO. Available online at: http://www.fao.org/fishery/statistics/ en (verified 11 October 2010).

FAO (2016). Cultured Aquatic Species Information Programme: Clarias gariepinus. Fisheries and Aquaculture Department, Food and Agricultural Organization of the United Nations, Rome.

FAO and NACA. (2001). Asia Diagnostic Guide to Aquatic Animal Diseases. FAO Fish.

Forster, J. (2008). Emerging Technologies in Marine Aquaculture. In Offshore Aquaculture in the United States: Economic Consideration, Implication and Opportunities (Ed. M. Rubino), pp 51-72.

Fredheim, A. and Langan, R. (2009). Advances in Technology for Off-shore and Open Ocean Aquaculture. In: New Technologies in Aquaculture: Improving Production Efficiency, Quality and Environmental Management [(Eds) G. Allen and G. Burnell], Cambridge, UK: Woodhead Publishing. pp. 914-944.

Glover, K.A., Hansen, M.M. and Skaala, O. (2009). Identifying the source of farmed escaped Atlantic salmon (Salmo salar): Bayesian clustering analysis increases accuracy of assignment. Aquaculture. 290: 37-46.

Grema, H.A., Geidam Y.A., Egwu G.O. (2011). Fish Production in Nigeria: An Update. Nigerian Veterinary Journal. 32(3): 40-51.

Groff, J.M. and La Patra, S.E. (2000). Infectious diseases impacting the commercial culture of Salmonids. Journal of Applied Aquaculture. 10(4): 17-90.

Houston, R.D., Haley, C.S., Hamilton, A., Guy, D.R., Mota-Velasco, J.C., Gheyas, A.A., Tinch, A.E., et al. (2010). The susceptibility of Atlantic salmon fry to freshwater infectious pancreatic necrosis is largely explained by a major QTL. Heredity. 105: 318-327.

Joffre, O.M., Klerkx, L., Dickson, M., Verdegem, M. (2017). How is innovation in aquaculture conceptualized and managed? A systematic literature review and reflection framework to inform analysis and action. Aquaculture. 470: 129-148. https://doi.org/10.1016/j. aquaculture.2016.12.020.

Joshua, A. and Omidiji, M.O. (2002). Rural development strategy in Nigeria, West and Central Africa. Paper presented at the international workshop on rural development in West and Central Africa. IITA, Ibadan. June 3-5.

Kocher, T.D., Lee, W.J., Sobolewska, H., Penman, D. and McAndrew, B. (1998). A genetic linkage map of a cichlid fish, the tilapia (Oreochromis niloticus). Genetics. 148(3): 1225-1232.

Kumar, G., Engle C.R. (2016). Technological advances that led to growth of shrimp, salmon and tilapia farming. Reviews in Fisheries Science and Aquaculture. 24: 136-152.

Lazard, J., Baruthio, A., Mathe, S., Rey-Valette, H., Chia, E., Clement, O., Aubin, J., Morissens, P., Mikolasek, O., Legendre, M., Levang, P., Blancheton, J.P. and Rene, F. (2010). Aquaculture system diversity and sustainable development: Fish farms and their representation. Aquatic Living Resources. 23: 187-198.

Madu, C.T., Okoye, F.E., Sado, E.K., Omorinkoba, W.S., Bankole, N.O. and Ita, E.O. (1984). A Preliminary Report of Induced Breeding Trials with the Mud Fish (Clarias anguillaris). KLRI Annual Report, Kainji Lake Research Institute, pp: 144-159. 
Mcarthur, M.J., Sachs, D.J. (2002). The Growth Competitiveness Index: Measuring Technological Advancement and the Stages of Development. In: The Global Competitiveness Report 2001-2002. [Porter, M.E., Sachs, J.D. et al (eds)], Oxford University Press, New York, pp 28-51.

Mcginnity, P., Prodöhl, P., Ferguson, A., Hynes, R., Maoiléidigh, N., Baker, N., Cotter, D., O'hea, B., Cooke, D., Rogan, G., Taggart, J. and Cross, T. (2003). Fitness reduction and potential extinction of wild populations of Atlantic salmon, Salmo salar, as a result of interactions with escaped farm salmon. Proceedings of the Royal Society of London B: Biological Sciences 270: 2443-2450.

Mendoza, R., De Dios, A., Vasquez, C., Cruz, E., Ricque, D. Aguilera, C. and Montemayor, J. (2001). Fishmeal replacement with feather-enzymatic hydrolyzates co-extruded with soyabean meal in practical diets for the Pacific white shrimp (Litopenaeus vannamei). Aquaculture Nutrition. 7(3): 143-151.

Mialhe, E., Bachere, E., Boulo, V., Cadoret, J.P., Rousseau, C., Cedeno, V. and Colwell, R.R. (1995). Future of biotechnologybased control of disease in marine invertebrates. Molecular Marine Biology and Biotechnology. 4(4): 275-283.

Muir, W.M (2005). Incorporation of competitive effects in forest tree or animal breeding programs Genetics. 170: 1247-1259.

National Research Council, (1988). National Research Council (US). Committee on Techniques for Estimating Probabilities of Extreme Floods, and National Research Council Staff. Estimating probabilities of extreme floods: Methods and Recommended Research. National Academies.

Naylor, R.L., Goldburg, R.J., Primavera, J.H., Kautsky, N., Beveridge, M.C.M., Clay, J., Folke, C., Lubchenko, J., Mooney, H. and Troell, C. (2000). Effect of aquaculture on world fish supplies. Nature. 405(6790): 1017-1024.

Nwachukwu, I. and Onuegbu, R. (2007). Adoption of Aquaculture technology by Fish Farmers in Imo State Nigeria. Journal of Technology Studies. 33(1): 57-64.

Ogah S.I, Kamarudin M.S, Nurul-Amin S.M, Puteri-Edaroyati M.W. (2020). Biological filtration properties of selected herbs in an aquaponic system. Aquaculture Research. 1-9. https://doi.org/10.1111/are.14526.

Ogah, S.I., Kamarudin, M.S., Nurul-Amin, S.M., Puteri-Edaroyati, M.W. (2020). Nutrient recycling through aquaponics and night-lighting. Journal of Environmental Biology. 41: 11131125.

OIE. (2000). Diagnostic Manual for Aquatic Animal Diseases. $3^{\text {rd }}$ edn. Office International des Epizooties, Paris, France, $237 \mathrm{pp}$.

Olokor, I.O., (1997). Solar tent an adoptable fish preservation technology in Kainji Lake Basin. Nigerian-German (GTZ) Kainji Lake Fisheries Promotion Project, New Bussa, Nigeria.

Oyeleye, O., (2003). Export potentials of smoked fish trade in Nigeria. The Guardian 19(8916): 27, Guardian Newspaper Publication, Lagos, Nigeria.

Ozigbo, E., Anyadike, C., Adegbite O., Kolawole P. (2014). Review of Aquaculture Production and Management in Nigeria. Journal of Experimental Agriculture. 4(10): 1137-1151.
Papatryphon, E. and Soares, J.H. (2001). The effects of phytase on apparent digestibility of four practical plant feedstuffs fed to striped bass, Moronesaxatilis. Aquaculture Nutrition. 7(3): 161-167.

Peeler, E.J., Murray, A.G., Thebault, A., Brun, E., Giovaninni, A. and Thrush, M.A. (2007). The application of risk analysis in aquatic animal health management. Preventive Veterinary Medicine. 81: 3-20.

Poggie, J.J. (1980). Small-scale fisherman's psychocultural characteristics and cooperative formation. Anthropology. Quarterly. 53: 1-3.

Pollnac, R.B. (1985). Social and cultural characteristics in small scale fishery development: Putting people first sociological variables in rural development. Marine and Freshwater Behaviour and Physiology. 23: 189-223.

Pulkkinen, K., Suomalainen, L.R., Read, A.F., Ebert, D., Rintamäki, P. and Valtonen, E.T. (2010). Intensive fish farming and the evolution of pathogen virulence: The case of Columnaris disease in Finland. Proceedings of the Royal Society B: Biological Science. 277: 593-600.

Quick, N.J., Middlemas, S.J. and Armstrong, J.D. (2004). A survey of antipredator controls at marine salmon farms in Scotland. Aquaculture. 230: 169-180.

Rao, P.S. and Sudha, P.M. (1996). Emerging Trends in Shrimp Farming. Fishing Chimes. 16: 25-26.

Refstie, S. and Åsgård, T.E. (2009). Advances in Aquaculture Feeds and Feeding: Salmonids. In New Technologies in Aquaculture: Improving Production Efficiency, Quality and Environmental Management, [(Eds) G. Allen and G. Burnell], Cambridge, UK: Woodhead Publishing. pp. 498-541.

Renault, T. (2009). Controlling Viral Diseases in Aquaculture: New Developments: New Technologies and Prospects. In: New Technologies in Aquaculture: Improving Production Efficiency, Quality and Environmental Management, ch. 9 [(eds) G. Burnell and G. Allan], Oxford, UK: Woodhead Publishing. pp. 244-266.

Ross, L.G., Handisyde, N. and Nimmo, D.C. (2009). Spatial Decision Support in Aquaculture: The Role of Geographical Information Systems and Remote Sensing. In: New Technologies in Aquaculture: Improving Production Efficiency, Quality and Environmental Management [(Eds) G. Allen and G. Burnell], Cambridge, UK: Woodhead Publishing. pp. 707-749.

Taylor, D.H. and Fearne, A. (2009). Demand management in fresh food value chains: A framework for analysis and improvement. Supply Chain Management: An International Journal. 14: 379-392.

Vielma, J., Makinen, T., Ekholm, P. and Koskela, J. (2000). Influence of dietary soy and phytase levels on performance and body composition of large rainbow trout (Oncorhynchus mykiss) and algal availability of phosphorus load. Aquaculture. 183(3-4): 349-362.

Waite, R., Beveridge, M., Brummett, R.E., Castine, S., Chaiyawannakarn, N., Kaushik, S., Mungkung, R., Nawapakpilai, S., Phillips, M. (2014). Improving productivity and environmental performance of aquaculture. Working Paper, Installment 5 of the Creating a Sustainable Future. World Resources Institute, Washington, DC. 
The Role of Technology in Nigerian Catfish Production: A Review

Walker, P. and Subasinghe, R. (eds.) (2000). DNA-based molecular diagnostic techniques: research needs for standardisation and validation of the detection of aquatic animal pathogens and diseases. Report and proceedings of the Expert Workshop on DNA-based Molecular Diagnostic Techniques: Research Needs for Standardization and Validation of the Detection of Aquatic Animal Pathogens and Diseases. Bangkok, Thailand, 7-9 February 1999, FAO Fish. Techn. Pap. No. 395: 93.

Walsh, D.M., Klyubin, I., Fadeeva, J.V., Cullen, W.K., Anwyl, R., Wolfe, M.S. and Selkoe, D.J. (2002). Naturally secreted oligomers of amyloid $\beta$ protein potently inhibit hippocampal long-term potentiation in vivo. Nature. 416(6880): 535-539.

Ward, A.J., Botham, M.S., Hoare, D.J., James, R., Broom, M., Godin, J.G.J., and Krause, J. (2002). Association patterns and shoal fidelity in the three-spined stickleback. Proceedings of the Royal Society of London. Series B: Biological Sciences. 269(1508): 2451-2455.
Watanabe, W.O., Ellis, S.C. and Chaves, J. (2001). Effects of Dietary Lipid and Energy to Protein Ratio on growth and Feed Utilization of Juvenile Mutton Snapper Lutjanus analis fed Isonitrogenous diets at two Temperatures. Journal of World Aquaculture Society. 32(1): 30-40.

Wong, A.C. and Van Eenennaam, A.L. (2008). Transgenic approaches for the reproductive containment of genetically engineered fish. Aquaculture. 275: 1-12.

Wuyep, S.Z.; Rampedi, I.T. (2018). Urban Fish Farming in Jos, Nigeria: Contributions towards Employment Opportunities, Income Generation and Poverty Alleviation for Improved Livelihoods. Agriculture. 8(7): 110-117. https://doi.org/ 10.3390/agriculture8070110

Yagi, N., Senda, Y., and Ariji, M. (2008). Panel data analyses to examine effects of subsidies to fishery productions in OECD countries. Fisheries Science. 74(6): 1229-1234. 